Review on Agriculture and Rural Development 2017 vol. 6 (1-2) ISSN 2063-4803

\title{
INVESTIGATION OF PHENOLOGICAL DEVELOPMENT OF SOME EPHEMERAL ANNUAL ORNAMENTAL PLANTS IN REGARD TO NITROGEN APPLICATION
}

\author{
KÁroly Ecseri ${ }^{1}$, JÁnos Ágoston ${ }^{1}$, Attila Hüvely ${ }^{1}$, Judit Pető ${ }^{1}$, Péter Honfi ${ }^{2}$ \\ ${ }^{1}$ Pallas Athena University, Faculty of Horticulture and Rural Development, Horticultural \\ Department \\ ${ }^{2}$ Szent István University, Faculty of Horticultural Science, Department of Floriculture and \\ Dendrology \\ ecseri.karoly@kfk.kefo.hu
}

\begin{abstract}
Nitrogen sensitivity of Cyanus segetum Hill. (cornflower), Consolida regalis GRAY. (larkspur) and Papaver rhoeas L. (poppy) was investigated in outdoor experiment with ammonium-nitrate fertilizer application. The aim of our study was to prove the harmful effect of fertilization on segetal vegetation degradation.

The examination method based on horizontal and vertical plant parameters, on phenological stages comparison.

The height of poppy was decreased significantly when $240 \mathrm{~kg} /$ ha nitrogen was applied. Significant vegetative growth was detected on the other two species investigated especially higher doses of nitrogen application. Nitrogen application had an adverse effect on cornflower stem strength. Stress tolerance of poppies was decreased in the highest application. The other two species was not detected any biotic or abiotic damage compared to the control and treated plots.
\end{abstract}

Keywords: cornflower, larkspur, poppy, fertilizer, archaeophytes

\section{INTRODUCTION}

Nitrogen plays a vital role in the physiology of plants. It is an essential building block of proteins and pigments. Not surprisingly there is a strict correlation between the nitrogen content of a leaf and photosynthesis, as enzymes participating in the Calvin-cycle and thylacoids give the vast majority of it is nitrogen content (EVANS, 1989). It is an easily mobilized macronutrient, which has influence on the plant's vegetative growth. Several factors affect the uptake (HARGITAI, 2005).

The applied complex fertilizer and ammonium nitrate significantly reduced the number of dicotyledonous species in the flora of the borders of arable land (PYŠEK AND LEPŠ, 1991). The negative effect of application of fertilizer, herbicide and their combination on archaeophytes examined in the trial was statistically proved in every treatment. During the trial the diversity of plant associations were reduced, however the weight of fresh biomass of the fertilized plots exceeded the untreated control (KLEIJN AND SCHNOEIJING, 1997, SCHMITZ, 2014). The diversity reduction effect of the application of fertilizers achieved by the enhanced growth and spread of high nutrient intake species. The number of lower nutrient intake - lower (between 3 and 4) Ellenberg $\mathrm{N}$-value - species gradually decreased. The rate of the damage rise in mid-term, which leads to the disappearance of certain species (SCHMITZ, 2014). Later regeneration of the slowly spreading species is difficult, because of the isolated populations where gene exchange is not possible (BISCHOFF AND MAHN, 2000). Because of the altered growth intensity of certain species the shading changes, which directly influences diversity. The dry weight of biomass was higher on the untreated plot, but individual plants grew higher on the treated ones, because of decreasing proportion of red/far red the tissues elongation. Application of fertilizers has an indirect 
influence on the diversity - through the modification of light conditions - of border associations of arable land (KLEIJN AND VAN DER VOORT, 1997). Similar, low biomass weight was observed in the case of application of $20 \mathrm{~kg} / \mathrm{ha}$ nitrogen. The competition between archaeophytes and cereals was not for the nitrogen, but for light. The effect of the nitrogen on competition is different in each species. Competition reaches it is height before flowering (IQBAL AND WRIGHT, 1997). Some researchers think, that nitrogen has a direct effect, which acts together with the competition. This can be the cause of the reaction of different species to fertilization which has no correlation with their ecological indicator value (PYŠEK AND LEPŠ, 1991).

\section{MATERIALS AND METHODS}

The trial was set up in 2016 at the Show Garden of the Faculty of Horticulture and Rural Development of Pallas Athena University ( $46^{\circ} 55^{\prime} 10^{\prime \prime} \mathrm{N}, 19^{\circ} 41^{\prime} 13$ " E). The soil is sand based, continuously cultivated, weed free. The setting up of plots and plowing to $20 \mathrm{~cm}$ depth was on $22^{\text {nd }}$ of February 2016. Even, aerated, small particle size sowing bed was made after plowing, 15 plots total was sown. Cornflower and delphinium seeds were incorporated 1-2 $\mathrm{cm}$ deep, poppy seeds were scattered on the surface. Sowing was not irrigated due to adequate soil moisture, the weather forecast predicted ample precipitation. During the trial we did not applied any form of agro- or phytotechnical method, the plants were extensively maintained.

Seeds quantities sown:

- Cyanus segetum:

- Consolida regalis:

$0.4 \mathrm{~g}$ (approx. 200 seeds)

$0.5 \mathrm{~g}$ (approx. 400 seeds)

- Papaver rhoeas (formula mixture): 0.04 g (approx. 400 seeds)

Plant species in the same treatment were put in one plot, there was a $30 \mathrm{~cm}$ walkway between treatments. The setting up of plots were made with a $50 \mathrm{~m}$ tape measure, the edges were marked with $50 \mathrm{~cm}$ wooden sticks. One plot was $1.5 \times 1.5 \mathrm{~m}$. The fertilizer (ammonium nitrate) was applied on $13^{\text {th }}$ of April, 2016 on the 12 plots. Each plot received $20.25 \mathrm{~g}, 40.5 \mathrm{~g}, 81 \mathrm{~g}$ and $162 \mathrm{~g}$, which is equivalent of $30,60,120,240 \mathrm{~kg} / \mathrm{ha}$ nitrogen active ingredient.

Measured an observed parameters, methodology:

- Observing the cotyledons, stems and leaves in comparison with the untreated plots especially on deformations, difference on leaf with, length, color, and general health of plants, once a week.

- Further observations on phenology, like plant width and height measurements before flowering, and height measurement after flowering, and assessing the ornamental value twice weekly from the beginning of flowering.

- Comparison of developmental speed based on horizontal and vertical plant parameters, on phenological stages.

The statistical assessments were made by using one or multifactorial analyses of variance (ANOVA, MANOVA) and multifactor correlation tests. Significant difference was determined by Tukey's test, Least Significant Difference and Games-Howell tests $(\alpha=0.05)$. For assaying we used SPSS 20 program (IBM, New York, US). 


\section{RESULTS AND DISCUSSION}

\section{Cyanus segetum}

During the analysis of data gathered at the assessment of $19^{\text {th }}$ of May Pearson's correlation analysis showed a close relationship within the 3 measurements (pairwise comparisons of width, length and height showed that the two-sided significance level was below 0.001 in each pairing) so these data were assessed together.

The 3 factorial MANOVA showed significant effect (Wilk's lambda value $F=5.436$, $\mathrm{SL}<0.001)$. Deviation within the groups in the case of width and length can be considered homogenous (Levine's test SL $>\alpha$ ), but was not fulfilled in the case of height, so for this parameter we used the Games-Howell test's result. Residues showed normal distribution on all 3 datasets (Kolmogorov-Smirnov test SL $>\alpha$ ).

Table 1. Comparative pairwise analysis on the effect of nitrogen application on Cyanus segetum's width and length

\begin{tabular}{|c|c|c|c|c|c|c|c|}
\hline \multirow{8}{*}{$\begin{array}{l}\text { Tukey } \\
\text { HSD }^{\mathrm{a}, \mathrm{b}, \mathrm{c}}\end{array}$} & \multirow{2}{*}{ TREATMENT } & \multirow{2}{*}{$\begin{array}{l}\text { Sample } \\
\text { size }\end{array}$} & \multicolumn{3}{|c|}{ WIDTH $(\mathrm{cm})$} & \multicolumn{2}{|c|}{ LENGTH $(\mathrm{cm})$} \\
\hline & & & 1 & 2 & 3 & 1 & 2 \\
\hline & Untreated & 20 & 14.25 & & & 14.65 & \\
\hline & $30 \mathrm{~kg} / \mathrm{ha}$ & 20 & & 18.75 & & 18.75 & 18.75 \\
\hline & $60 \mathrm{~kg} / \mathrm{ha}$ & 20 & & 20.25 & 20.25 & & 19.05 \\
\hline & $120 \mathrm{~kg} / \mathrm{ha}$ & 20 & & 22.25 & 22.25 & & 22.60 \\
\hline & $240 \mathrm{~kg} / \mathrm{ha}$ & 20 & & & 23.30 & & 22.40 \\
\hline & Sig. & & 1.000 & 0.086 & 0.177 & 0.063 & 0.094 \\
\hline
\end{tabular}

Examining the plant's width the pairwise comparison shows 3 significantly distinct groups $(\mathrm{SL}<0.05)$. Table 1. shows that the untreated plants had the smallest inflorescence size compared to all other treatment. Significant difference was shown only between the smallest (30 kg/ha) and highest $(240 \mathrm{~kg} / \mathrm{ha})$ doses of nitrogen. $30 \mathrm{~kg} / \mathrm{ha}$ dose of nitrogen have not had size increasing effect compared to the untreated. Statistically supported difference was shown at 60,120 and $240 \mathrm{~kg} / \mathrm{ha}$ doses (Table 1.)

Table 2. Pairwise analysis of the effect of nitrogen treatment of Cyanus segetum (assessment dates are $19^{\text {th }}$ of May and $8^{\text {th }}$ of July in 2016.)

\begin{tabular}{|c|c|c|c|c|c|c|}
\hline \multirow[t]{2}{*}{ TREATMENT } & \multirow[t]{2}{*}{$\begin{array}{l}\text { Sample } \\
\text { size }\end{array}$} & \multicolumn{2}{|c|}{$\begin{array}{c}\text { HEIGHT }(\mathrm{cm}) \\
19^{\text {th }} \text { of May } \\
2016 .\end{array}$} & \multirow[t]{2}{*}{ TREATMENT } & \multicolumn{2}{|c|}{$\begin{array}{l}\text { HEIGHT }(\mathrm{cm}) \\
8^{\text {th }} \text { of July } 2016 .\end{array}$} \\
\hline & & 1 & 2 & & 1 & 2 \\
\hline Untreated & 20 & 13.55 & & Untreated & 73.85 & \\
\hline $30 \mathrm{~kg} / \mathrm{ha}$ & 20 & & 21.25 & $120 \mathrm{~kg} / \mathrm{ha}$ & 79.10 & 79.10 \\
\hline $240 \mathrm{~kg} / \mathrm{ha}$ & 20 & & 21.45 & $30 \mathrm{~kg} / \mathrm{ha}$ & & 84.25 \\
\hline $60 \mathrm{~kg} / \mathrm{ha}$ & 20 & & 23.20 & $240 \mathrm{~kg} / \mathrm{ha}$ & & 84.30 \\
\hline $120 \mathrm{~kg} / \mathrm{ha}$ & 20 & & 24.90 & $60 \mathrm{~kg} / \mathrm{ha}$ & & 85.25 \\
\hline
\end{tabular}

Games-Howell test showed similar result in regard of plant height (Table 2). In this case plants were also significantly smaller $(\mathrm{SL}<0.05)$ in the untreated plot at the time of the first assessment. There was no significance detected between the nitrogen treatments.

Assessment made when plants finished their vertical growth $\left(8^{\text {th }}\right.$ of July). ANOVA data analysis showed significant effect $(\mathrm{F}=2.698 \mathrm{SL}=0.035<\alpha)$. Normality was accepted based 
on kurtosis and skew. Based on post hoc test (Least Significant Difference) all treatments except $120 \mathrm{~kg} / \mathrm{h}$ nitrogen - enhanced the plants final height $(\mathrm{SL}<0.05)$.

\section{Consolida regalis}

A close relationship was also observed in this case within the 3 measurements (Pearson's correlation $\mathrm{SL}<0.01)$. MANOVA showed a strong significance $(\mathrm{F}=4.600, \mathrm{SL}<0.001)$. Normality test was carried out with the inspection of skew and kurtosis of residues (were between +1.5 and -1.5 interval in both datasets, TABACHNICK AND FIDELL, 2013). Treatments had significant effect only in the case of width and length. Levine's test was acceptable only in width (SL $>\alpha$ ) while in length we used Games-Howell test.

Table 3. Comparative pairwise analysis on the effect of nitrogen application on Consolida regalis width and length

\begin{tabular}{|c|c|c|c|c|c|c|c|}
\hline \multirow{2}{*}{ TREATMENT } & Sample & \multicolumn{3}{|c|}{ WIDTH $(\mathrm{cm})$} & \multicolumn{3}{c|}{ LENGTH $(\mathrm{cm})$} \\
\cline { 3 - 8 } & size & 1 & 2 & 3 & 1 & 2 & 3 \\
\hline Untreated & 20 & 14.00 & & & 12.10 & & \\
\hline $30 \mathrm{~kg} / \mathrm{ha}$ & 20 & 17.10 & 17.10 & & & 15.40 & \\
\hline $120 \mathrm{~kg} / \mathrm{ha}$ & 20 & & 19.45 & 19.45 & & 17.05 & 17.05 \\
\hline $60 \mathrm{~kg} / \mathrm{ha}$ & 20 & & 19.90 & 19.90 & & 18.40 & 18.40 \\
\hline $240 \mathrm{~kg} / \mathrm{ha}$ & 20 & & & 20.60 & & & 19.55 \\
\hline Sig. & & 0.092 & 0.158 & 0.881 & & & \\
\hline
\end{tabular}

Taking a closer look on the width of plants we can determine, that - the exception of smallest nitrogen dose - all treatments had significant effect on at least one horizontal parameter of a plant. Between the treatments only the smallest and highest doses had verifiable differences $(\mathrm{SL}<0.05)$. The values of length had similar results, with the difference that for this dimension all treatments had significantly bigger plant sizes compared to untreated plants (Table 3.).

Table 4. Pairwise analysis of the effect of nitrogen treatment of plant height of Consolida regalis $\left(8^{\text {th }}\right.$ of July 2016).

\begin{tabular}{|c|c|c|c|c|}
\hline \multirow{4}{*}{$\begin{array}{c}\text { Tukey } \\
\text { HSD }\end{array}$} & \multirow{2}{*}{ TREATMENT } & $\begin{array}{c}\text { Sample } \\
\text { size }\end{array}$ & \multicolumn{2}{|c|}{$\begin{array}{c}\text { HEIGHT }(\mathrm{cm}) \\
8^{\text {th }} \text { of July } \\
2016 .\end{array}$} \\
\cline { 3 - 5 } & & & 1 & 2 \\
\cline { 2 - 5 } & Untreated & 20 & 65.40 & \\
\cline { 2 - 5 } & $120 \mathrm{~kg} / \mathrm{ha}$ & 20 & & 82.85 \\
\cline { 2 - 5 } & $30 \mathrm{~kg} / \mathrm{ha}$ & 20 & & 83.00 \\
\cline { 2 - 5 } & $60 \mathrm{~kg} / \mathrm{ha}$ & 20 & & 86.15 \\
\cline { 2 - 5 } & $240 \mathrm{~kg} / \mathrm{ha}$ & 20 & & 88.35 \\
\cline { 2 - 5 } & Sig. & & 1.000 & 0.879 \\
\hline
\end{tabular}

Height measurements assessed at the end of the trial showed significant effect $(\mathrm{F}=4.871$ $\mathrm{SL}<0.01$ ). The normality test of residues (Kolmogorov-Smirnoff test, SL> $\alpha$ ), and the Levine's test $(\mathrm{SL}>\alpha)$ showed statistically proven difference $(\mathrm{SL}<\alpha)$ between the untreated and treated plants vertical increase (Table 4). 


\section{Papaver rhoeas}

Investigating the width and length of poppy we have found correlation (Pearson's correlation $\mathrm{SL}<0.001)$.

The normality test was accepted for the residuals of both dataset (Kolmogorov-Smirnov test $\mathrm{SL}>\alpha$ ), but in this case treatments had no significant effect on horizontal parameters of the plants (MANOVA $\mathrm{F}=1.567 \mathrm{SL}=0.176>\alpha$ ).

The data of height showed normal distribution (investigation of skew and kurtosis). Treatments had strong significant effect on the vertical dimensions of plants (ANOVA $\mathrm{F}=4.463, \mathrm{SL}<0.01)$. Based on the results of Levine's test $(\mathrm{SL}>\alpha)$ for pairwise comparison we used Tukey's test.

Table 5. Comparative pairwise analysis on the effect of nitrogen application on Papaver rhoeas height (19 ${ }^{\text {th }}$ of May 2016)

\begin{tabular}{|c|c|c|c|c|c|}
\hline \multirow{4}{*}{ Tukey } & \multirow{2}{*}{ TREATMENTS } & Sample & \multicolumn{3}{|c|}{ HEIGHT $(\mathrm{cm})$} \\
\cline { 4 - 6 } & & size & 1 & 2 & 3 \\
\cline { 2 - 6 } HSD $^{\text {a,b }}$ & $30 \mathrm{~kg} / \mathrm{ha}$ & 20 & 13.30 & & \\
\cline { 2 - 6 } & Control & 20 & 14.20 & 14.20 & \\
\cline { 2 - 6 } & $60 \mathrm{~kg} / \mathrm{ha}$ & 20 & 18.70 & 18.70 & 18.70 \\
\cline { 2 - 6 } & $240 \mathrm{~kg} / \mathrm{ha}$ & 20 & & 20.95 & 20.95 \\
\cline { 2 - 6 } & $120 \mathrm{~kg} / \mathrm{ha}$ & 20 & & & 21.70 \\
\cline { 2 - 6 } & Sig. & & 0.230 & 0.074 & 0.771 \\
\hline
\end{tabular}

Results show, only the $120 \mathrm{~kg} / \mathrm{ha}$ dose differed in this phenophase from the untreated $(\mathrm{SL}<0.05)$. Nobody should make far-reaching conclusions from this data, because the assessment was made at the beginning of flower stem growth (Table 5).

Table 6. Pairwise analysis of the effect of nitrogen treatment of plant height of Papaver rhoeas height $\left(8^{\text {th }}\right.$ of July 2016)

\begin{tabular}{|c|c|c|c|}
\hline \multirow{2}{*}{ TREATMENTS } & \multirow{2}{*}{$\begin{array}{c}\text { Sample } \\
\text { size }\end{array}$} & \multicolumn{2}{|c|}{$\begin{array}{c}\text { HEIGHT }(\mathrm{cm}) \\
\text { 8th of July 2016. }\end{array}$} \\
\cline { 3 - 4 } & & 1 & 2 \\
\hline $240 \mathrm{~kg} / \mathrm{ha}$ & 20 & 84.50 & \\
\hline $120 \mathrm{~kg} / \mathrm{ha}$ & 20 & 95.30 & 95.30 \\
\hline $30 \mathrm{~kg} / \mathrm{ha}$ & 20 & 96.55 & 96.55 \\
\hline $60 \mathrm{~kg} / \mathrm{ha}$ & 20 & & 102.40 \\
\hline Untreated & 20 & & 106.00 \\
\hline
\end{tabular}

Height measurements made at the end of the growing cycle showed altered results. The conducted statistical tests (ANOVA F=5.717 SL $<0.001$, Levene's test $\mathrm{SL}<\alpha$, normality of residues) and the Games-Howell test showed the negative effect of treatments (Table 6). Plant size decreased with the higher dose of treatment, and became significant at $240 \mathrm{~kg} / \mathrm{ha}$ compared to the untreated control $(\mathrm{SL}<0.01)$.

\section{CONCLUSIONS}

Vegetative growth by application of nitrogen fertilizer was statistically proven in our trial in the case of Cyanus segetum and Consoloda regalis, which corresponds earlier 
references. Treatments however had no effect on the width and length of Papaver rhoeas, moreover instead of helping the elongation of internodes plant height stagnated or decreased.

We observed other effect of nitrogen over fertilization. In cornflower - which is often prone to falling over - nitrogen application increased elongation, which decreased the wind resistance of plants. Weed coverage was the same as in the untreated plot, but floppy plants were aesthetically disturbing at the end of flowering. Biotic stress tolerance was not impaired, the pests severity (mostly aphids) was identical with the untreated plot, and had no effect on flowering. On the Consolida regalis plots we could not detect any biotic or abiotic damage caused by the treatments. The only abnormality we saw was the twisting of flower stalks, but it was also present in the untreated plot. Weed coverage was higher on the untreated plot, because of smaller plant sizes, but this had no effect on it is decorative value. On the leaves of Papaver rhoeas distortion, chlorotic blotches were observed, some plants died. Also increased aphid infestation occurred at the beginning of flower stalk formation, mainly on the treatments of 120 and $240 \mathrm{~kg} / \mathrm{ha}$.

\section{REFERENCES}

BisCHOFF, A., MAHN, E-G. (2000): The effects of nitrogen and diaspore availability on the regeneration of weed communities following extensification. Agriculture, Ecosystems and Environment. Vol. 77, pp. 237-246.

Evans, J. R. (1989): Photosyntesis and nitrogen relationship in leaves of $\mathrm{C}_{3}$ plants. Oecologia. Vol. 78, Nr. 1, pp. 9-19.

HARgitai L. (2005): Talajtan és agrokémia II. Alkalmazott talajtan és agrokémia. Budapesti Corvinus Egyetem, Kertészettudományi Kar. Budapest. pp. 161-174.

IQBAL, J., WRIGHT, D. (1997): Effects of nitrogen supply on competition between wheat and three annual weed species. Weed Research. Vol. 37, pp. 391-400.

KleiJn, D., SchnoeiJing, G. I. J. (1997): Field boundary vegetation and the effects of agrochemical drifts: botanical change caused by low levels of herbicide and fertilizer. Journal of Applied Ecology. Vol. 34, pp. 1413-1425.

KleIJN, D., VAN DER VOORT, A. C. L. (1997): Conservation headlands for rare arable weeds: the effects of fertilizer application and light penetration on plant growth. Biological Conservation. Vol. 81, pp. 57-67.

PYŠEK, P., LEPŠ, J. (1991): Response of weed community to nitrogen fertilization: a multivariate analysis. Journal of Vegatation Science. Vol. 2, pp. 237-244.

SCHMitz, J., HAHN, M., BRÜHL, C. A. (2014): Agrochemicals in field margins - An experimental field study to assess the impacts of herbicides and fertilizers on a natural plant community. Agriculture, Ecosystems and Environment. Vol. 193, pp. 60-69.

TABACHNick, B. G., FIDEll, L. S. (2013): Using Multivariate Statistics. 6th edition. Boston: Pearson. pp. 96-97. 